\title{
Kerusakan Usus pada Mencit (Mus musculus) yang Diinokulasi Larva 3 (L3) Anisakis spp.
}

\section{Intestinal Damage in Mice (Mus musculus) Inoculated with Third Stage larvae (L3) Anisakis spp.}

\author{
Febrina Dian Permatasari ${ }^{1}$, Poedji Hastutiek ${ }^{1}$, Lucia Tri Suwanti ${ }^{2}$ \\ ${ }^{1}$ Departemen Parasitologi Veteriner, Fakultas Kedokteran Hewan, Universitas Airlangga \\ ${ }^{2}$ Peneliti Insitute Tropical Diseases \\ Email: drhfebrinadianp@gmail.com
}

\begin{abstract}
This study aims to be show damage in the intestine of mice caused by inoculation of the larvae of Anisakis spp. alive and who has died because of a warming $75^{\circ} \mathrm{C}$ for 7 minutes. Eighteen male mice (Mus musculus) were divided into three groups: control group, a group of mice were inoculated the larvae of Anisakis spp. alive and groups of mice were inoculated the larvae of Anisakis spp. who have died. 48 hours post inoculation, the mice's intestines necropsy performed later performed HE staining to identify and scoring intestinal histopathology. The results showed inoculation of the larvae of Anisakis spp. either alive or dead induce histological changes in the intestine in the form of infiltration of inflammatory cells, epithelial changes and structural changes in the intestinal mucosa.
\end{abstract}

Keywords: Third stage larvae Anisakis spp., Intestinal damage, histopathology, Mus musculus

\begin{abstract}
Abstrak
Penelitian ini bertujuan untuk melihat gambaran kerusakan pada usus mencit yang ditimbulkan akibat inokulasi larva Anisakis spp. dalam keadaan hidup dan yang telah mati karena mengalami pemanasan $75^{\circ} \mathrm{C}$ selama 7 menit. Delapan belas ekor mencit (Mus musculus) dibagi menjadi tiga kelompok yaitu kelompok kontrol, kelompok mencit yang diinokulasi larva Anisakis spp. dalam keadaan hidup dan kelompok mencit yang diinokulasi larva Anisakis spp. yang telah mati. 48 jam post inokulasi, dilakukan nekropsi usus mencit untuk kemudian dilakukan pewarnaan HE untuk mengidentifikasi dan skoring histopatologi usus. Hasil penelitian menunjukkan inokulasi larva Anisakis spp. baik dalam keadaan hidup maupun mati menimbulkan perubahan gambaran histologi pada usus berupa infiltrasi sel radang, perubahan epitel dan perubahan struktur mukosa pada usus.
\end{abstract}

Kata kunci : Larva tiga Anisakis spp., kerusakan usus, histopatologi, Mus musculus

\section{Pendahuluan}

Anisakiasis merupakan infeksi parasit pada manusia dan hewan yang disebabkan oleh larva nematoda dari famili Anisakidae yaitu Anisakis spp. yang memiliki predileksi pada usus ikan. Larva Anisakis banyak ditemukan pada ikan dan mamalia laut di laut utara, samudra Atlantik dan samudra Pasifik bagian utara. Penelitian menunjukkan bahwa prevalensi $80 \%$ ikan terdapat parasit ini
(Daschneret al., 2012). Kasus anisakiasis tersebar di berbagai belahan dunia, terutama daerah atau negara dengan konsumsi ikan mentah tinggi yang menjadi salah satu penyebab paling umum alergi makanan (Lindqvist et al., 1993). Manusia terinfeksi Anisakis spp. bila memakan ikan mentah, penggaraman dan pengasapan kurang sempurna. Pemasakan kurang matang yang mengandung larva Anisakis spp. yang dapat menginduksi dua masalah utama yang sering 
dikaitkan dengan gejala klinis mirip dengan infeksi bakteri atau virus gastroenteritis.

Belum banyak informasi tentang kejadian Anisakis di Indonesia. Pengamatan Hariyadi (2006) pada ikan di beberapa perairan Indonesia menunjukkan prevalensi larva Anisakidae yang cukup tinggi pada ikan Ekor Kuning di Selat Sunda sebesar 67\%, Laut Bali sebesar 67\% dan Laut Nusa Tenggara Timur sebesar 17\%, ikan Tuna di Laut Bali menunjukkan prevalensi larva Anisakidae sebesar 67\% dan Laut Nusa Tenggara Timur sebesar 17\% dan prevalensi larva Anisakidae pada ikan Kerapu di Selat Sunda sebesar 25\%, Laut Bali sebesar 43\% dan Laut Nusa Tenggara Timur sebesar 17\%.

Pasien yang terkena Anisakiasis terutama berasal dari antigen somatik yang berasal dari larva hidup atau mati (Moneo et al., 2005) pada produk ikan yang disebabkan allergen dari Anisakis spp. yang tahan terhadap panas dan pepsin yaitu protein Tropomyosin (Caballero et al., 2008). Meskipun dimasak pada $70^{\circ} \mathrm{C}$ atau didinginkan $-20^{\circ} \mathrm{C}$ selama 72 jam yang diyakini dapat menghancurkan infektivitas parasit ini, namun ternyata kemampuan untuk mendenaturasikan protein tidak dapat dihilangkan (Caballero and Moneo 2004). Pengasapan dan penggaraman dengan menggunakan lemon atau cuka juga tidak dapat membunuh parasit ini terbukti larva $A$. simplex dapat bertahan dalam cuka hingga 51 hari (Oshima, 1972). Penelitian yang dilakukan oleh Raharjo (2016) tentang preservasi pangan memberikan hasil bahwa memasak ikan laut dengan metode pemanasan dengan suhu $75^{\circ} \mathrm{C}$ selama tujuh menit mematikan seluruh larva Anisakis spp., namun hal ini belum dibuktikan apakah protein Tropomyosin terdenaturasi atau tidak hingga dapat menimbulkan perubahan histologi pada usus. Perlu penelitian apakah larva
Anisakis spp. baik dalam keadaan hidup atau mati akan mengakibatkan perubahan histopatologi pada usus mencit jika diinokulasikan secara oral yang nantinya hasil penelitian ini akan membuktikan apakah larva Anisakis spp. yang telah mati tetap dapat menimbulkan kerusakan pada usus.

\section{Materi dan Metode}

Penelitian ini menggunakan hewan coba mencit jantan sebanyak 18 ekor, alkohol absolut, $70 \%, 80 \%, 90 \%$ dan $96 \%$, xylene, parafin cair, xylol, antibodi IFN- $\gamma$ (D-17) Sc-9344 Santa Cruz Biotechnology, antibodi TNF- $\alpha$ (52B83) Sc-52746 Santa Cruz Biotechnology, Endogen Peroksida $0,5 \%$, antigen retrieval declocking chamber, Phospat Buffer Saline (PBS) pH 7,4, sniper, universal link, Trekavidin-HRP label, DAB, substrat buffer, hematoxylin, dan aquades.

Peralatan penelitian yang digunakan adalah kandang hewan coba, sonde mencit, tempat minum, mikroskop cahaya Nikon Eclipse $C i \AA$, opti lab, spuit satu cc, gloves, masker, kapas steril, ,papan seksi, dissecting set, timbangan digital.

Prosedur penelitian meliputi: koleksi larva Anisakis spp sebanyak 200 larva, identifikasi larva Anisakis spp berdasarkan Iglesias et al.,(2001), pemanasan larva Anisakis spp sebanyak 60 larva dengan suhu $75^{\circ} \mathrm{C}$ selama tujuh menit dengan menggunakan microwave. Terdapat tiga kelompok perlakuan, yaitu kelompok kontrol, perlakuan 1 dan perlakuan 2 masing-masing kelompok terdapat enam ekor mencit. Kelompok kontrol tidak diberikan perlakuan apapun, perlakuan 1 masing-masing mencit diinokulasi sepuluh larva Anisakis spp.tanpa pemanasan secara oral, dan perlakuan 2 masing masing mencit diinokulasi secara oral sepuluh larva 
Anisakis spp yang telah dipanaskan, pembedahan mencit dan pengamatan gambaran histologi kerusakan pada usus mencit dengan pewarnaan HE. Data gambaran histopatologi yang diperoleh dianalisis secara non parametrik dengan skoring berdasarkan (Erben et al., 2014) dan diuji KruskalWallis. Analisis data dilakukan dengan menggunakan perangkat lunak komputer SPSS 23 for windows.

\section{Hasil dan Pembahasan}

Hasil identifikasi larva Anisakis spp. yang terlihat pada pewarnaan carmin dengan perbesaran 40x. Pada bagian anterior dapat terlihat boring tooth yang memiliki fungsi untuk membantu larva Anisakis spp. saat penetrasi pada jaringan, pada esophagus bagian dorsal memiliki peran untuk sekresi enzim ekstracorporeal (Buzzel and Sommerville, 1985) dan sebagai tempat mensekresikan produk ES yaitu tropomyosin.

Pada bagian posterior larva Anisakis spp. tipe I terdapat mucron, inilah yang membedakannya dengan Anisakis tipe II dan pada bagian ventrikal tampak ventrikulus lebih panjang dibandingkan dengan Anisakis tipe II yang memiliki ventrikulus lebih pendek (Mattiucci et al., 2013).
Hasil histopatologi kelompok kontrol, kelompok mencit yang diinokulasi larva Anisakis spp. dalam keadaan hidup dan kelompok yang diinokulasi larva Anisakis spp. yang telah mati yaitu pada kelompok kontrol terlihat vili normal dan tidak terdapat infiltrasi sel radang. Pada kelompok P1a dengan perbesaran 200x terlihat bentukan granuloma dan vili ruptur dan jika dilihat dengan perbesaran 400x (Gambar P1b) terlihat bentukan granuloma terdiri dari jaringan ikat, eosinofil, neutrofil, limfosit, dan makrofag. Pada kelompok P2 dengan perbesaran 400x terlihat infiltrasi sel radang namun tidak membentuk bentukan granuloma, terdapat abses kripta dan irregular kripta.

Tingkat nekrosis pada kelompok kontrol memiliki nilai rata-rata 0 , pada kelompok mencit yang diinokulasi larva Anisakis spp. dalam keadaan hidup menunjukkan nilai rata-rata sebesar 20,33 dan kelompok mencit yang diinokulasi larva Anisakis spp. yang telah mati memiliki nilai rata-rata sebesar 12,50. Pada mencit yang diinokulasi larva Anisakis spp. dalam keadaan hidup memiliki nilai rata-rata lebih tinggi dibandingkan dengan mencit yang diinokulasi larva Anisakis spp. yang telah mati, ini memiliki arti larva hidup Anisakis spp. lebih banyak menimbulkan nekrosis.
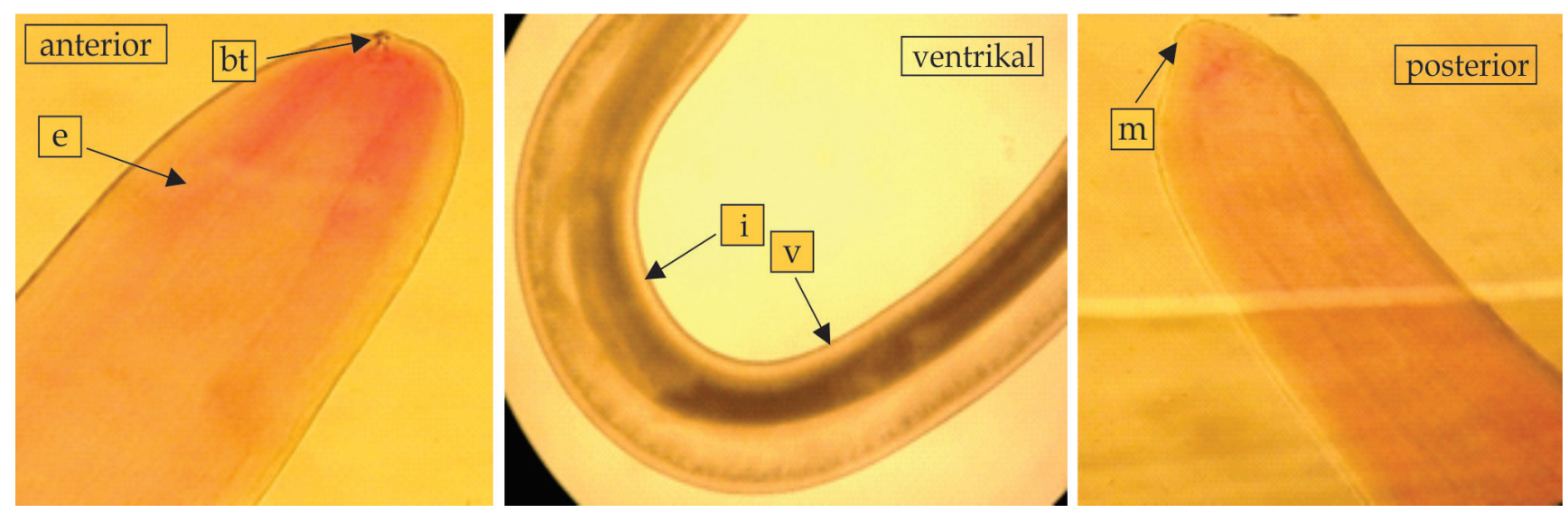

Gambar 1 Identifikasi larva Anisakis spp. dengan perbesaran 40x Keterangan e: esophagus; bt: boring tooth; i: intestinal; v: ventrikulus; m: mucron. 

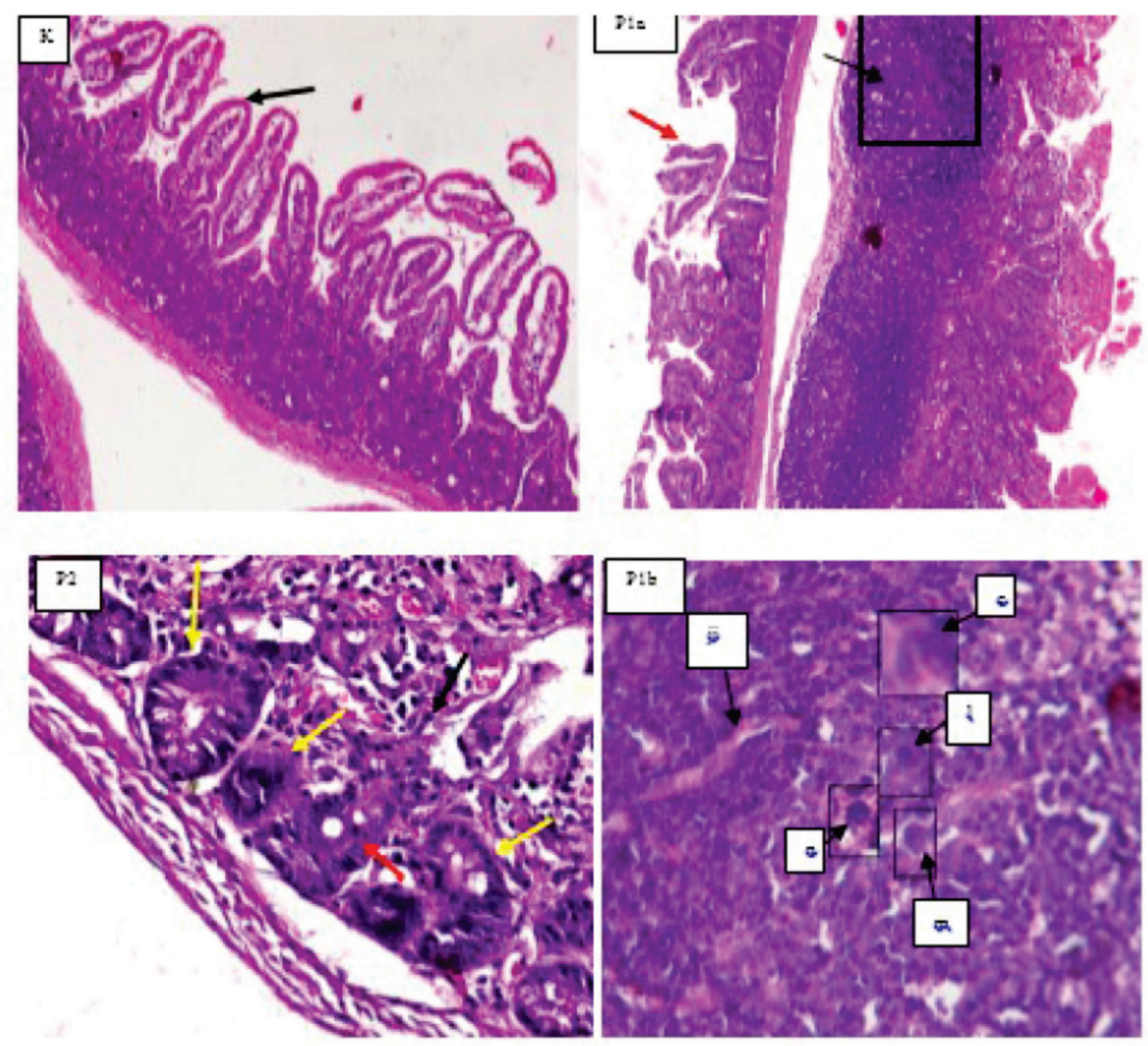

Gambar 2. Gambaran histopatologi usus mencit dengan pewarnaan HE.

Keterangan:

K : Kontrol usus mencit perbesaran 200x. Tanda panah hitam menunjukkan vili normal.

P1a: usus mencit yang diinokulasi larva Anisakis spp. dalam keadaan hidup perbesaran 200x. Tanda panah hitam menunjukkan bentukan granuloma dan tanda panah berwarna merah menunjukkan vili ruptur.

P2 : usus mencit yang diinokulasi larva Anisakis spp. yang telah mati. Tanda panah berwarna hitam menunjukkan infiltrasi sel radang. Tanda panah berwarna merah menunjukkan kripta abses. Tanda panah berwarna kuning menunjukkan irregular kripta.

P1b: usus mencit perbesaran 400x. Keterangan: ji: jaringan ikat; 1: limfosit; m: makrofag; e: eosinophil; n: neutrophil.

Tabel 1. Rerata dan Simpangan Baku nekrosis usus mencit yang diinokulasi larva Anisakis spp. secara oral

\begin{tabular}{cc}
\hline $\begin{array}{c}\text { Kelompok } \\
\text { perlakuan }\end{array}$ & $\begin{array}{c}\text { Nekrosis } \\
(\mathbf{X} \pm \mathbf{S B})\end{array}$ \\
\hline $\mathrm{K}(-)$ & $0,00^{\mathrm{a}} \pm 0,00$ \\
$\mathrm{P} 1$ & $20,33^{\mathrm{b}} \pm 4,274$ \\
$\mathrm{P} 2$ & $12,50^{\mathrm{b}} \pm 7,064$ \\
\hline
\end{tabular}

Keterangan : Superskrip yang berbeda pada kolom yang sama menunjukkan terdapat perbedaan yang nyata $(\mathrm{P}<0,05)$

Setelah dikonsumsi, larva bisa dieliminasi baik dengan dimuntahkan dan dikeluarkan melalui feses. Larva Anisakis spp. dapat menembus dinding saluran pencernaan. Sebagai konsekuensi yang terakhir, terjadi reaksi granulomatosa lokal (Mattiucci et al., 2011) hal ini sependapat dengan hasil penelitian bahwa hasil histopatologi pada usus mencit yang diinfeksi larva hidup Anisakis spp. menimbulkan lesi granuloma (Gambar 2).

Hasil penelitian menunjukkan histopatologi pada usus mencit yang diinokulasi larva hidup Anisakis spp. lebih berat dibandingkan dengan larva Anisakis spp. yang telah mati berdasarkan referensi menurut Erben et al., (2014) (Lampiran 1), hal ini sependapat dengan Audicana and Kennedy (2008) bahwa larva yang masih hidup dapat menyebabkan sensitisasi dengan cara mengeluarkan enzim 
proteolitik yang diperlukan untuk penetrasi jaringan dengan menggunakan boring tooth (Fukuda et al., 1990) dan melepaskan protein eksresi-sekresi yaitu tropomyosin yang disimpan dalam kelenjar eksretori parasit (excretory gland) (Gomez-aguado et al., 2003), ventrikulus dan permukaan luminal dari epitel usus parasit (Caballero et al., 2008) yang memiliki sifat resistensi yang tinggi terhadap pemanasan dan digesti oleh enzim pepsin.

Larva Anisakis spp. dalam keadaan hidup seandainya terpotong sebagian atau sepertiga bagian tubuhnya, larva ini tetap mempertahankan invasinya pada jaringan gastrointestinal hingga bagian submukosa (Asami and Inoshita, 1967) namun kemungkinan untuk menginduksi produksi antibodi spesifik masih belum jelas.

Perlakuan pemanasan pada larva Anisakis spp. tidak dapat merusak ikatan IgE-protein tropomyosin yang memiliki berat molekul rendah yaitu $41 \mathrm{kDa}$ yang tahan terhadap panas dan berpotensi menyebabkan alergi (Moneo et al., 2005).

Kesimpulan dari penelitian ini adalah Inokulasi larva Anisakis spp. baik dalam keadaan hidup maupun mati menimbulkan perubahan gambaran histology pada usus berupa infiltrasi sel radang, perubahan epitel dan perubahan struktur mukosa pada usus. Perlu dilakukan penelitian lebih lanjut untuk mengetahui apakah terdapat produk respon imun yang mungkin berkontribusi terhadap terjadinya kerusakan pada usus yang diinokulasi larva Anisakis spp.

\section{Kesimpulan}

Hasil penelitian menyimpulkan bahwa inokulasi larva Anisakis spp. baik dalam keadaan hidup maupun mati menimbulkan perubahan gambaran histologi pada usus berupa infiltrasi sel radang, perubahan epitel dan perubahan struktur mukosa pada usus.

\section{Ucapan Terima Kasih}

Ucapan terimakasih sebesar-besarnya kepada Allah SWT, orang tua Achmad Effendi A.Ma dan ibunda tercinta Suyanti serta adik Achmad Zulkifli dan Achmad Thoriq Ivanda yang selalu memberikan dukungan dan semangat serta bantuan doa dan materiil. Semua staff dan karyawan di Lab Patologi Veteriner Fakultas Kedokteran Hewan Universitas Airlangga yang telah mengerjakan preparat untuk pewarnaan HE.

\section{Daftar Pustaka}

Asami K and Inoshita Y (1967) Experimental anisakiasis in guinea pigs: Factors influencing infection of larvae in the host. Japanese $J$ of Parasitol 16: 415-422.

Audicana, T.M and Kennedy, M.W. 2008. Anisakis simplex: from obscure infectious worm toinducer of immune hypersensitivity. Clin Microbiol Rev. 21(2):360-379.

Buzzell, G.R and Sommerville, R.I (1985) The structure of the oesophagus in the third-stage infective larva of Anisakis sp. (Nematoda: Anisakidae). Trans Am Microsc Soc. 104: 86-94.

Caballero, M.L and Moneo, I (2004)Several allergens from Anisakis simplex are highly resistant to heat and pepsin treatments. Parasitol Res. 15:1-7.

Caballero, M.L. Moneo, I. Gomez-Aguado, F. Corcuera, M.T. Casado, I and Rodriguez- Perez, R (2008) Isolation of Ani s 5, an excretorysecretory and highly heat-resistant allergen useful for the diagnosis of Anisakis larvae sensitization. Parasitol Res. 103(5):1231-1233.

Daschner, A. Cuéllar, C and Rodero, M.,2012. The Anisakis allergy debate: does an evolutionar- 
yapproach help? Trends Parasitol.28:9-15. http://dx.doi.org/10.1016/j.pt.2011.10.001. Diakses pada tanggal 7 Agustus 2016.

Erben, U. Loddenkemper, C. Doerfel, K. Spieckermann, S. Haller, D. Heimesaat, M.M. Zeitz, M. Siegmund, B and Kühl, A.A (2014) A guide to histomorphological evaluation of intestinal inflammation in mouse models. Int $J$ Clin Exp Pathol. 7(8):4557-4576.

Fukuda T, Tongu Y and Ishii A (1990) Ultrastructural changes in the oesophagus, intestine, and excretory organ of larval Anisakis (Ascaridoidea: Nematoda) after incubation in arti®cial gastric juice. Jpn J Parasitol 39: 1-6.

Gomez-Aguado, F. Picazo, A. Caballero, M.L. Moneo, I. Asturias, J.A and Corcuera, M.T (2003) Ultrastructural localization of Ani s 1, a major allergen from the fish parasite Anisakis simplex. Parasitol Res. 89:379-380.

Hariyadi, A.S (2006) Pemetaan infestasi cacing parasitik dan risiko zoonosis pada ikan laut di perairan Indonesia Bagian Selatan. Bogor. IPB.

Iglesias, L. Valero, A. Banitez, R. and Adroher, F.J (2001) In vitro cultivation of anisakissimplex: pepsin increases survival and moulting from fourth larval to adult stage. Parasitol. 123:285291.

Lindqvist, A. Ikezawa, Z. Tanaka, A and Yman, L (1993) Seafood specific IgE in atopic dermatitis. Ann Allergy. 70:58.
Mattiucci, S. Paoletti, M. Borrini, F. Palumbo, M. Palmieri, R.M and Gomes, V (2011) First molecular identification of the zoonotic parasite Anisakis pegreffii (Nematoda: Anisakidae) in a paraffin-embedded granuloma taken from a case of human intestinal anisakiasis in Italy. BMC Infect Dis. 11:82.

Mattiucci, S. Fazii, P. De Rosa, A. Paoletti, M. Megna, A. S. Glielmo, A. De Angelis, M. Costa, A. Meucci, C. Calvaruso, V. Sorrentini, I. Palma, G. Bruschi, F and Nascetti, G (2013) Anisakiasis and gastroallergic reactions associated with Anisakis pegreffii infection, Italy. Emerg Infect Dis, 19:496-499.

Moneo, I. Caballero, M.L. Gonzalez-Munoz, M. Rodriguez-Mahillo, A.I. Rodriguez-Perez, R and Silva, A (2005) Isolation of a heat-resistant allergen from the fish parasite Anisakis simplex. Parasitol Res.96: 285-289.

Oshima, T (1972) Anisakisand Anisakiasis in Japan and adjacent areas. Prog Med Parasitol Jpn. 4:305-393.

Raharjo, H.M (2016) Pengaruh Waktu Preservasi Fillet Ikan Kerapu (Epinephelus sp) Dengan Pemanasan, Pendinginan dan Pengaraman Terhadap Daya Tahan Hidup Larva Anisakidae. Tesis. Magister Ilmu Penyakit dan Kesehatan Masyarakat Veteriner Fakultas Kedokteran Hewan Universitas Airlangga 